\title{
MOTOR PERFORMANCE AND NUTRITIONAL STATUS IN STUDENTS WITH ATTENTION DEFICIT HIPERACTIVITY DISORDER
}

\author{
Erika Morgana Felix do Nascimento ${ }^{1}$, Andressa Ribeiro Contreira ${ }^{2}$, Eva Vilma Alves da Silva ${ }^{3}$, \\ Luciano Portes de Souza ${ }^{4}$, Thais Silva Beltrame ${ }^{5}$
}

\begin{abstract}
Objective: This Study aimed to characterize the motor development and nutritional status of scholars with ADHD indicative. Methods: Eighty scholars of both sexes, aged $12,30 \pm 1,16$ years old participated; separated in groups with $(n=40)$ and without ADHD indicative. To identify ADHD and Motor Development were used respectively, the Hyperactivity and Attention Deficit Evaluation Scale, and the motor battery MABC-2. Height and weight were measured to calculate Body Mass Index. Data were analyzed on SPSS17 software, adopting $p<0,05$ significance levels. Results: The subjects presented, in most, a normal motor development. The ADHD group showed most numbers of subjects with a "defined motor problem". It was found a statistically difference on throwing and catching skills $(p=0,005)$, balance $(p=0,010)$ and general motor development $(p=0,014)$ which without ADHD group presents better performance. It wasn't found any significative association between motor development and ADHD presence. The scholars showed adequate nutritional state for age, but didn't present a statistically significative difference between groups. Besides that, many subjects in both groups were classificated as overweight. An inverse relation between nutritional status and balance was found on with ADHD group $(r=-0,321)$. Conclusions: There was difference in balance skills and abilities manuals, with poorer motor performance presented by the group with ADHD. They also found that the higher the BMI of children with ADHD worse performance in the balance
\end{abstract}

Key words: motor performance; nutritional status; attention deficit hyperactivity disorder.

\section{INTRODUCTION}

There is an increase in research on developmental disorders last years, primarily on motor disorders associated with problems such as Attention Deficit Disorder and Hyperactivity Disorder (ADHD) and Developmental Coordination Disorder $(D C D)^{1-6}$. These studies have highlighted deficiencies in motor skills due to developmental delay, attention deficit and changes in the brain, resulting in dysfunction of neurotransmitters.

Studies in motor development also call attention to the importance of nutritional assessment ${ }^{7,8}$, due it being a source of information about the health status of a population, in this case the child population. Through these techniques, it is possible to establish changes related to malnutrition or overweight, which can cause health problems such as cardiovascular disease, blood pressure, diabetes, cancer, and others ${ }^{9,10,11}$. In Brazil, data show that the number of overweight children represents a jump of 20 percentage points in 20 years ${ }^{12}$. According to these data, one in three children aged 5 to 9 years are overweight and $14.3 \%$ are obese. Besides that, it was verified weight deficit at $4.1 \%$ of children in this age group.

Researches ${ }^{1,3,13-15}$ have found associations between limitations on motor performance and $A H^{6}$ and between motor difficulties and overweight ${ }^{11,16.17}$. The knowledge about the disorders (learning, motor or attention) comes from studies in pediatric population and the number of investigations found about adolescents and adults is significantly low ${ }^{18,19}$.

\footnotetext{
1 PhD in Sports Sciences - Universidade de Trás-os-Montes e Alto Douro (UTAD).

2 MSc in Human Movement Science - Universidade do Estado de Santa Catarina (UDESC) Maringá/PR.

3 PhD in Sports Sciences - Universidade de Trás-os-Montes e Alto Douro (UTAD).

4 MSc in Human Movement Science - Universidade do Estado de Santa Catarina (UDESC) Curitiba/PR.

$5 \mathrm{PhD}$ in Human Movement Science (UFSM). Professora do Programa de Pós-Graduação em Ciências do Movimento Humano da Universidade do Estado de Santa Catarina (UDESC) Florianópolis/SC.

Study developed in the Laboratory of Learning Disorders and Development (LADADE) linked to the Center for Health Sciences and Sport at the University of Santa Catarina State (CEFID / UDESC).

Corresponding author: andressa_contreira@yahoo.com.br
}

Suggested citation: Nascimento EMF, et al. Motor performance and nutritional status in students with attention deficit hiperactivity disorder. Journal of Human Growth and Development 2013; 23(2): 358-364

Manuscript submitted Aug 28 2013, accepted for publication Oct 152013. 
Several studies have been developed in Brazil and in the world, characterizing the motor behavior and motor profile of children with ADHD $^{3,6,20-22}$. However there are few national and global studies identifying nutritional characteristics in adolescents with attention disorder ${ }^{11,16,19,23}$, what is really important to better characterize their health conditions ${ }^{23}$. According with a systematic review study conducted by Shaw et al. ${ }^{19}$, the obesity issue on ADHD researches is less reported in the literature, and shows to be relevant in the current study because obesity is increasing in all countries. In the case of children and adolescents, AgranatMeged et al. ${ }^{23}$ claim that ADHD may act as a risk factor to develop an abnormal feed habit, which reinforces the need to research this theme.

Thus, the present study shows scientific relevance to characterize the motor performance and nutritional status of schoolchildren with indicative of Attention Deficit Disorder and Hyperactivity Disorder (ADHD).

\section{METHOD}

The research was conducted in accordance with resolution $N^{\circ} 196 / 96$ of the National Health Council (NHC) and approved by the Ethics and Human Research Committee (EHRC) at Universidade do Estado de Santa Catarina (UDESC) (Protocol $\left.n^{\circ} 106 / 2010\right)$.

\section{Participants}

The school in which the study was conducted serves about 3,000 students in kindergarten, elementary and high school, being located in São José / SC. According to pedagogical team, 1.216 subjects ranging in age from 11 to 14 years (the target age group of the study) were identified.

From this number of subjects (1.216) was calculated a representative sample of 300 students. They were evaluated according to the motor performance, indicative of ADHD and nutritional status. After these assessments 40 students were identified with indicative of ADHD (13.3\%). In view of the purpose of the study to characterize the motor performance and nutritional status of schoolchildren with ADHD indication, it was considered necessary to establish a control group for comparison.

Therefore we conducted a random raffle with 260 students who showed no indication of disorder, constituting a group of 40 students. Therefore, were part of the final group of 80 participating students, of both sexes, aged 11 to 14 years (mean age $12,30 \pm 1,16$ years), divided into the following groups: "with indicative of $\operatorname{ADHD}(\mathrm{n}=40)$ and "without indicative of ADHD" ( $n=40)$.

Inclusion criteria were: age criteria (11-14 years), lack of physical and mental problems that prevented the testing, delivery of consent term signed by parents or guardians allowing the participation of children in study.

\section{Data Collection}

Data collection occurred after the approval of EHRC / UDESC in a specific place provided by the school, during the moment the subjects were at school.

All researchers involved in the study were previously trained to apply the tests. Students were individually assessed and advised to wear clothing appropriate during the tests and before each evaluation they performed attempts to become familiar with the instrument.

\section{Instruments}

It was used the scale for assessment of attention deficit disorder and hyperactivity disorder - EDA-H ${ }^{24}$ formed by 20 closed questions that characterize the Disorder inherent symptoms in the family and sTablechool environment, being applied to parents and teachers.

The score rating scale refers to: Hyperactivity / Impulsivity e" ten; Attention Deficit $\mathrm{e}^{\prime \prime}$ ten; $\mathrm{e}^{\prime \prime} 11$ Conduct Disorder, Attention Deficit Hyperactivity e" 18 ; and Overall e" 30 . The total result of the subscales indicates that when the score is greater than or equal to 30 points the subject is rated with prevalence of overall ADHD symptoms (associated with conduct disorder). To identify students with ADHD indicative, the scale responses completed by parents and teachers pointing the behavioral characteristics of students in both environments (home / school) were compared.

Motor performance was evaluated by the Movement Assessment Battery for Children 2 $M A B C 2^{25}$, used to detect motor difficulties in children and adolescents aged between three and 16 years. The test covers Manual Dexterity, Aiming \& Catching (ball skills) and Balance (static and dynamic) with different complexities for each age (age band one: three to six years; age band two: seven to ten years; age band three: 11 to 16 years). In this study, specifically, was used the range three. The evaluation results are calculated using the MABC2 Total values, compared in the table of percentiles, as the protocol requires. Children whose total score is below the fifth percentile, should be considered with an indication of motor difficulty, values between the fifth and 15 th percentile indicate that the child has some motor difficulty (risk of motor difficulty), and values above the 15 th percentile indicating a normal motor development.

It was assessed body mass (Plenna Weighing Scale) and height (Cardiomed stadiometer) to calculate Body Mass Index (BMI). To determine the nutritional status were used references of the World Health Organization ${ }^{26}$.

\section{Data An Data Analysis}

It was used the Statistical Package for Social Sciences - SPSS 17 for Windows, through descriptive and inferential statistics. The normality test of 
Kolmogorov Smirnov ( $\mathrm{n}>50$ ) was performed to check the distribution of data for the following variables: age, weight, height and total scores of the MABC - 2; as they did not follow the normality criteria, non-parametric tests were used. The Spearman correlation coefficient was used to analyze the relationship between BMI and motor skills; and the $U$ test (Mann Whitney) to compare motor performance between "with ADHD" and "without ADHD" groups.

A binary logistic regression analysis was used to verify any association between variables "with movement difficulty" and "indicative of ADHD". The variables were included in the test in dichotomous form (zero $=$ normal; one $=$ at least one problem: hyperactivity / impulsivity, attention deficit disorder, conduct disorder, hyperactivity + attention deficit, overall associated with the conduct disorder). The variable "movement difficulty" had three response levels (zero $=$ no movement difficulty, one $=$ risk of movement difficulty, two = with movement difficulty) and entered as a dummy variable. To all analyzes were established a significance level of $5 \%$.

\section{RESULTS}

It was found that in both groups most students had normal motor development (with ADHD: 90\%; without ADHD: 85\%). About indicative of motor difficulties, four subjects were identified in the group "with ADHD" and only one in "without ADHD".

Comparing the motor performance in MABC2 skills categories (Table 1 ), a statistically significant difference has occurred in of Aiming \& Catching skills, Balance skills and MABC-2 total, with the worst performance in with ADHD group. Verifying the association between the motor classification and ADHD indicative (Table 2), we found no significant association.

Figure 1 shows the frequency distribution of subjects' nutritional status where can be observed that most subjects, in both groups, has normal weight. When comparing BMI between groups of students with and without ADHD (Table 3 ) there was no statistically significant difference between groups.

Table 1: Motor performance comparison by skill category of students with ADHD indicative $(n=40)$ and without ADHD indicative $(n=40)$, Florianópolis/SC, Brazil, 2010

\begin{tabular}{|c|c|c|c|c|c|c|c|}
\hline Skills & Disorder & Mean & SD & Median & Mean Rank & $\mathbf{U}$ & $\mathbf{P}$ \\
\hline Manual & With ADHD & 25,31 & 18,32 & 25 & 40,88 & 785 & 0,883 \\
\hline Dexterity & Without ADHD & 24,12 & 15,76 & 25 & 40,13 & & \\
\hline Aiming \& & With ADHD & 45,20 & 27,73 & 50 & 33,30 & 512 & $0,005^{*}$ \\
\hline Catching & Without ADHD & 63,82 & 23,90 & 75 & 47,70 & & \\
\hline \multirow{2}{*}{ Balance } & With ADHD & 47,20 & 32,39 & 37 & 34,04 & 541,50 & $0,010 *$ \\
\hline & Without ADHD & 65,30 & 28,60 & 77 & 46,96 & & \\
\hline \multirow{2}{*}{ TOTAL } & With ADHD & 47,20 & 32,39 & 37 & 34,15 & 546 & $0,014^{*}$ \\
\hline & Without ADHD & 44,09 & 22,61 & 37 & 46,85 & & \\
\hline
\end{tabular}

$\mathrm{U}=$ Mann Whitney $\mathrm{U}$ test, $\mathrm{p}=$ significance index.

* Difference statistically significant at $p<0.05$.

Table 2: Association between motor ratings and the indicative of ADHD, Florianópolis/SC, Brazil, 2010

$\begin{array}{lccc}\text { MABC-2 Motor Performance } & \text { OR } & \text { CC } \mathbf{9 5 \%} & \text { P } \\ \text { Without difficulty } & 1 & & \text { n.s } \\ \text { Risk of difficulty } & 0,86 & 0,19-3,94 & \text { n.s }\end{array}$

n.s $=$ Not significant 


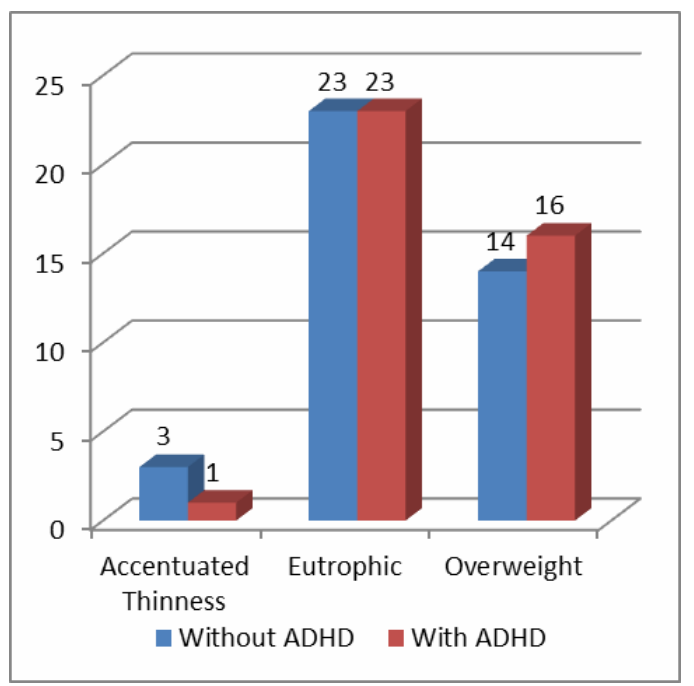

Figure 1 - Frequency distribution for classification of nutritional status of children with $A D H D(n=40)$ and without ADHD $(n=40)$, Florianópolis/SC, Brazil, 2010

Table 3: Comparison of BMI among children with ADHD $(n=40)$ and without ADHD $(n=40)$, Florianópolis/ SC, Brazil, 2010

\begin{tabular}{cccccccccc} 
Nutritional Status & Disorders & N & Mean & SD & Median & Mean Rank & U & P \\
& With ADHD & 40 & 19,55 & 3,21 & 19,39 & 42,41 & 723,50 & 0,462 \\
\cline { 3 - 3 } & Without ADHD & 40 & 19,02 & 3,29 & 19,00 & 38,59 &
\end{tabular}

BMI: Body Mass Index; $U=$ Mann Whitney $U$ test, $p=$ significance level;

* statistically significant at $p<0.05$

Checking the relationship between BMI and motor performance of students with and without ADHD by category of skills, the results revealed a statistically significant relationship between BMI and poor balance skill $(r=-0.321, p<0.05)$ for "with ADHD" group. These results indicate that the variables are related the higher the BMI, the worse the performance in balance skill. A significant relationship wasn't found for skills. No significant correlation between BMI and motor skills were found in "without ADHD" group.

\section{DISCUSSION}

Most students in both groups were classified with normal motor development, which is corroborated by other researches 27,28 . It was also found that children with ADHD had a higher occurrence in defined motor problem (motor difficulty) classification. According Kadesjo and Gillberg ${ }^{20}$ half of individuals with ADHD have moving difficulty due to lack of attention and behavior problems. This assertion is corroborated by another study ${ }^{3}$ in which motor skills of children with ADHD subtypes were investigated, finding that about $50 \%$ of boys in each group had problems in motor performance compared to the control group. The authors comment that the motor difficulties of these children range from 8 to $50 \%$, due to the fact that symptoms of distractibility and impulsivity stand out to the observation of motor problems and associated impacts ${ }^{3}$.

Comparing motor performance by skill category, a significant difference was found in Aiming $\&$ Catching and Balance skills, and motor performance overall, with worst performance for with ADHD group. According to Sangster et al. ${ }^{14}$ children with ADHD have slow movements, with variations and lower precision, making them with more motor disadvantages than children without ADHD. Remember that is not established in the literature in which activities children with ADHD have higher deficits and have been shown different results for each skill.

The results of this study are compatible with results of an investigation ${ }^{3}$ which found greater deficits in performance of ball skills in students with ADHD types of inattentive and hyperactive/impulsive when compared to control group. For balance skills, unlike the present study, the authors found no differences in performance between groups.

In other research ${ }^{13}$, significant differences were found in fine motor skills, balance and visual- 
motor control with improved performance for the group without ADHD. Poeta and Rosa Neto 22 complement that children with ADHD, due to changes in fine motor coordination, may also have difficulties in school learning and everyday activities. Given the different results observed in the literature, highlights that attention and concentration problems affect not only the appropriate balance development, but also in all motor skills².

Checking the association between ADHD and motor classification, it wasn't found significant association. This result is corroborated by Mostofsky et al. ${ }^{29}$ in a study which was used neuroimaging to assess children with ADHD during the performance of a simple motor task. The authors found decreased activation in the motor cortex and no change during skill task, suggesting no relations between them. The motor disorders in individuals with ADHD only manifest when ADHD presents itself genetically more severe, it may mean that there are specific types of genes for ADHD without presenting association with motor difficulties ${ }^{30}$.

Unlike the present study, Miyahara et al. ${ }^{15}$ found significant associations of anomalous responses of children with ADHD in brain activation performing motor tasks of tapping fingers. Kaplan et al. ${ }^{1}$ evaluated individuals with learning and attention disabilities and with typical development, finding high prevalence of DCD and comorbidity degrees of DCD with other developmental disorders, such as attention deficit and hyperactivity disorder. These problems appear together due to proximity between two brain areas (prefrontal cortex and cerebellum) responsible for cognition and motor control ${ }^{21}$.

On nutritional status, the results indicate that most students with and without ADHD were eutrophic, however it was observed for both groups a high frequency of overweight subjects, yet, there was no significant difference between students with and without ADHD. Studies show that overweight can be explained by physical inactivity and habits acquired through development ${ }^{7,9,10}$. Moreover, these studies ${ }^{9,10}$ also discuss about sedentary trend among teenagers favoring weight gain and predisposing to disease in adulthood. Reportedly the Diagnostic and Statistical Manual of Mental Disorders ${ }^{31}$, individuals with ADHD would be, by definition, more active than typical individuals, presenting excessive ample motor activity and difficulty participation in sedentary activities.

We believe that these excessive motor characteristics could give them a greater caloric expenditure compared to peers without the disorder of attention, but the results of this study revealed that children with ADHD were overweight /obese individuals as well as typical, which may suggest that both have similar lifestyles. Other studies evaluating mental health and overweight/obesity prevalence in children and adolescents found that both have similar body satisfaction as children and adolescents with normal weight ${ }^{11,16}$.

The information cited above are in line with one of the studies reported in the systematic literature review about ADHD, which found that obesity may be a comorbid of attention disorder, although studies that address this issue are still scarce in the literature, which recently received focus because of an increasing in obesity index in worldwide. In a study ${ }^{19}$ with adults in obese treatment, found ADHD prevalence in most obese, which may occur due to brain dopamine or dysfunction in the insulin receptor. According to the authors further research is needed to explain the association between ADHD and obesity. Agranat-Meged et al. ${ }^{23}$ corroborate these claims finding in their study with 26 children in school age, of both sexes, more than half of them suffered from ADHD comorbid, which led the authors to infer that the disorder may be a risk factor for the development of an abnormal feeding.

About correlation between BMI and motor skills, it was found a weak and negative relationship between balance and overweight variables only for "with ADHD" group, indicating that the higher the BMI the worse the balance. Berleze et al. ${ }^{32}$ investigated the motor performance of obese children and found that they were classified as early and elementary stages of motor patterns. The authors found that obesity influences negatively the process and product performance of fundamental motor skills, causing the kids to quit of systematic practices, which would cause inactivity and restriction of motor activities. Aleixo et al. ${ }^{17}$ support our results verifying the influence of overweight and obesity in balance skills in schoolchildren aged 6 to 10 years, global praxis and postural changes, finding that overweight and obese schoolchildren showed deficits in balance and fulfillment motor activities, as well as performing everyday activities.

Another study ${ }^{33}$ examined the coordination level in schoolchildren, verifying that scholars with overweight/obesity had low levels of coordination. The nutritional status may interfere in children motor skills performance, which may have influenced the results of the cited study. These findings corroborate the findings of this research showing a negative correlation between nutritional status and balance skills. In another investigation ${ }^{34}$ sought to relate BMI and gross motor skill showing that there was no significant correlation. The authors believe that motor development occurs in the same way for all children, not restricting the movement by body weight.

Thus, it was found that most subjects in both groups showed normal motor development and appropriate nutritional classification for age, and there is also occurrence of overweight for both groups. It was observed a difference in balance skills and manual dexterity, with worst motor performance presented by the "with ADHD" group. It was also found that the higher BMI the worse performance in balance.

\section{Thanks:}

Foundation for Research Support of the State of Amazonas (FAPEAM) protocol number 5655.55.5410.21032011. 


\section{REFERENCES}

1. Kaplan BJ, Wilson BN, Dewey D, Crawford SG. DCD may not be a discrete disorder. Hum Mov Sci. 1998; 17(4): 471-90.

2. Cypel, S. A. Criança com déficit de atenção e hiperatividade: atualização para pais, professores e profissionais da saúde. São Paulo: Lemos; 2000.

3. Pitcher TM, Piek JP, Hay MD. A. Fine and Gross motor ability in males with ADHD. Dev Med Child Neurol. 2003; 45 (8):525-35.

4. Suzuki S, Gugelmim MRG, Soares AV. O equilíbrio estático em crianças em idade escolar com transtorno de déficit de atenção/ hiperatividade. Fisioter Mov. 2005; 1(3): 49-54.

5. Coppede AC, Okuda PMM, Capellini SA. Desempenho motor de escolares com dificuldades de aprendizagem em função motora fina e escrita. J. Hum. Growth Dev. 2012; 22 (3): 283-290.

6. Silva J, Contreira AR, Capistrano R, Beltrame TS. Desempenho motor de escolares com e sem Transtorno do Déficit de Atenção/Hiperatividade (TDAH). ConsSaude. 2012; 11 (1): 76-84.

7. Medeiros CCM, Cardoso MAA, Pereira RAR, Alves GTA, França ISX, Coura AS et al. Estado nutricional e hábitos de vida em escolares. J. Hum. Growth Dev. 2011; 21 (3): 789-797.

8. Feferbaum R, Leone C, Nogueira RC, Cavalcanti PN, Cardoso EB, Serra MA. Avaliação antropométrica e por bioimpedância de um programa de educação nutricional para escolares na faixa etária de 7 a 14 anos durante o período de 10 meses. J. Hum. Growth Dev. 2012; 22 (3): 283-290.

9. Amaral APA, Palma AP. Perfil epidemiológico da obesidade em crianças: relação entre televisão, atividade física e obesidade. R. bras. Ci. e Mov. 2001; 9 (4): 19-24.

10. Farias ES, Salvador MRD. Antropometria, composição corporal e atividade física de escolares. Rev Bras Cineantropom Desemp Hum. 2005; 7(1): 21-29.

11. Wardle J, Cooke L. The impact of obesity on psychological well-being. Best Pract Res Clin Endocrinol Metab. 2005; 19 (3): 421-40.

12. Instituto Brasileiro de Geografia e Estatística IBGE. POF 2008/2009 - Antropometria e estado nutricional de crianças, adolescentes e adultos no Brasil. Rio de Janeiro: IBGE; 2010.

13. Tseng $M H$, Henderson A, Chow SM, Yao G. Relationship between motor proficiency, attention, impulse, and activity in children with ADHD. Dev Med Child Neurol. 2004; 46 (6):381-8.

14. Sangster $\mathrm{CA}$, Beninger $\mathrm{C}$, Polatajko HJ, Mandich A. Cognitive strategy generation in children with developmental coordination disorder. Can J Occup Ther. 2005; 72 (2): 67-77.
15. Miyahara M, Piek J, Barrett N. Accuracy of drawing in a dual-task and resistance-todistraction study: motor or attention deficit? Hum Mov Sci. 2006; 25 (1):100-9.

16. Melnyk, BM, Small L, Morrison-Beedy D, Strasser A, Spath A, Kreipe R et al. Mental health correlates of healthy lifestyle attitudes, beliefs, choices, and behaviors in overweight adolescents. J Pediatr Health Care. 2006; 20 (6): 401-6.

17. Aleixo AA, Elaine LG, Walsh IAP, Pereira K. Influência do sobrepeso e da obesidade na postura, na praxia global e no equilíbrio de escolares. J. Hum. Growth Dev. 2012; 22 (2): 239-245.

18. Rohde LA, Mattos P. Principios e práticas em transtorno de déficit de atenção e hiperatividade. Porto Alegre: Artmed; 2003.

19. Shaw M, Hodgkins P, Caci H, Young S, Kahle J, Woods AG. et al. A systematic review and analysis of long-term outcomes in attention deficit hyperactivity disorder: effects of treatment an non-treatment. Bio Med Central. 2012; 10:99.

20. Kadesjo B, Gillberg C. Attention deficits and clumsiness in Swedish 7-year-old children. Dev Med Child Neurol. 1998; 40 (12): 796-804.

21. Diamond A. Close interrelational of Motor Development and of the Cerebellum and Prefrontal Cortex. Child Dev. 2000; 71 (1): 44-56.

22. Poeta LS, Rosa Neto F. Intervenção motora em uma criança com transtorno do déficit de atenção/hiperatividade TDAH. Lecturas Educación Física y Deportes. 2005; 10(89).

23. Agranat-Meged AN, Deitcher C, Goldzweig G, Leibenson L, Stein M, Galili-Weisstub E. Chidhood obesity and Attention Deficit/ Hyperactivity Disorder: a newly describal comorbidity in obese hospitalized children. Int J Eat Disord. 2005; 37 (4): 357-359.

24. Farré A, Narbona J. EDAH: Escala para la evalución del transtorno por déficit de atención con hiperactividad. Madrid: TEA Ediciones; 2001.

25. Henderson S, Sugden DA, Barnett A. Movement assessment battery for children. 2 ed. San Antonio: Harcourt Assessment; 2007.

26. Organização Mundial de Saúde - OMS. Classificação do estado nutricional para adolescentes de 10 a 19 anos, 2007. Disponível em: <http://nutricao.saude.gov.br/sisvan. Php? Conteúdo=curvas_cresc_oms $>$.

27. Nascimento EMF, Contreira AR, Beltrame TS. Desempenho motor de escolares com idade entre 11 e 14 anos de Florianópolis-SC. ConsSaude. $2011 ; 10$ (2):231-238.

28. Silva J, Beltrame TS, Oliveira AVP, Sperandio FF. Dificuldades motoras e de aprendizagem em crianças com baixo desempenho escolar. J. Hum. Growth Dev. 2012; 22 (1): 789-797. 
29. Mostofsky SH., Rimrodt SL, Schafer JG, Boyce A, Goldberg MC, Pekar JJ et al. Atypical motor and sensory cortex activation in attentiondeficit/hyperactivity disorder: a functional magnetic resonance imaging study of simple sequential finger tapping. Biol Psychiatry. 2006; 59 (1):48-56.

30. Thapar A, Langley K, Asherson P, Gill M. Geneenvironment interplay in attention deficit hyperactivity disorder and the importance of a developmental perspective. Br J Psychiatry. 2007; 190: 1-3.

31. Dornelles C. Manual diagnóstico e estatístico de transtornos mentais. Trad. - DSM-IV-tr. 4 ed. rev. Porto Alegre: Artmed; 2002. pg 113 e 116.
32. Berleze A, Haeffner LSB, Valentini NC. Desempenho motor de crianças obesas: uma investigação do processo e produto de habilidades motoras fundamentais. Rev Bras Cineantropom Desemp Hum. 2007; 9(2): 134-144.

33. Pelozin F, Folle A, Collet C, Botti M, Nascimento, JV. Nível de coordenação motora de escolares de 09 a 11 anos da rede estadual de ensino da cidade de Florianópolis/SC. Rev Mackenzie Educ Fís Esporte. 2009; 8 (2):123-132.

34. Catenassi FZ, Marques I, Bastos CB, Basso L, Ronque VER, Gerage AM. Relação entre índice de massa corporal e habilidade motora grossa em crianças de quatro a seis anos. Rev Bras Med Esporte. 2007; 13 (4): 227-230. 